\title{
Phaeobacter leonis sp. nov., an alphaproteobacterium from Mediterranean Sea sediments
} \author{
Frédéric Gaboyer $^{1,2,3}$, Brian J. Tindall ${ }^{4}$, Maria-Cristina Ciobanu ${ }^{1,2,3}$, Frédérique Duthoit $^{1,2,3}$,
Marc Le Romancer ${ }^{1,2,3}$ and Karine Alain ${ }^{1,2,3}$
}

\footnotetext{
${ }^{1}$ Université de Bretagne Occidentale (UBO, UEB), Institut Universitaire Européen de la Mer (IUEM) - UMR 6197, Laboratoire de Microbiologie des Environnements Extrêmes (LMEE), Place Nicolas Copernic, F-29280 Plouzané, France

${ }^{2}$ CNRS, IUEM - UMR 6197, Laboratoire de Microbiologie des Environnements Extrêmes (LMEE), Place Nicolas Copernic, F-29280 Plouzané, France

${ }^{3}$ Ifremer, UMR6197, Laboratoire de Microbiologie des Environnements Extrêmes (LMEE), Technopôle Pointe du diable, F-29280 Plouzané, France

4 DSMZ - Deutsche Sammlung von Mikroorganismem und Zellkulturen Gmbh. Inhoffenstr. 7bN D-38124 Braunschweig. Germany
}

*: Corresponding author : Frédéric Gaboyer, email address : Frederic.Gaboyer@univ-brest.fr

\begin{abstract}
:
A novel Gram-stain-negative, strictly aerobic, heterotrophic bacterium, designated $306^{\top}$, was isolated from near-surface (109 $\mathrm{cm}$ below the sea floor) sediments of the Gulf of Lions, in the Mediterranean Sea. Strain $306^{\top}$ grew at temperatures between 4 and $32{ }^{\circ} \mathrm{C}$ (optimum $17-22{ }^{\circ} \mathrm{C}$ ), from pH 6.5 to 9.0 (optimum 8.0-9.0) and between 0.5 and $6.0 \%(\mathrm{w} / \mathrm{v}) \mathrm{NaCl}$ (optimum 2.0\%). Its DNA G+C content was $58.8 \mathrm{~mol} \%$. On the basis of $16 \mathrm{~S}$ rRNA gene sequence similarity, the novel isolate belongs to the class Alphaproteobacteria and is related to the genus Phaeobacter. It shares $98.7 \% 16 \mathrm{~S}$ rRNA sequence identity with Phaeobacter arcticus, its closest phylogenetic relative. It contained Q-10 as the only respiratory quinone, $\mathrm{C}_{18: 1} \omega 7 \mathrm{C}$ and $\mathrm{C}_{16: 0}$ as major fatty acids $(>5 \%)$ and phosphatidylethanolamine, phosphatidylglycerol, phosphatidylcholine, diphosphatidylglycerol, two unidentified lipids and an aminolipid as polar lipids. The chemotaxonomic data are consistent with the affiliation of strain $306^{\top}$ to the genus Phaeobacter. Results of physiological experiments, biochemical tests and DNA-DNA hybridizations (with $P$. arcticus) indicate that strain $306^{\circ}$ is genetically and phenotypically distinct from the five species of the genus Phaeobacter with validly published names. Strain $306^{\top}$ therefore represents a novel species, for which the name Phaeobacter leonis sp. nov. is proposed. The type strain is $306^{\top}\left(=\mathrm{DSM} 25627^{\top}=\right.$ CIP $\left.110369^{\top}=\mathrm{UBOCC} 3187^{\top}\right)$.
\end{abstract}




\section{Main text}

The genus Phaeobacter was introduced by Martens et al. (2006), after reclassification of Roseobacter species as members of the genus Phaeobacter on the basis of common genetic and phenotypic characteristics. The genus Phaeobacter incorporates Gram-stain-negative, aerobic, chemoorganoheterotrophic, ovoid or rod-shaped, motile strains containing Q-10 as the main respiratory quinone. In November 2012, this genus encompassed five species: Phaeobacter gallaeciensis was isolated from cultures of a bivalve mollusc (Martens et al., 2006; Ruiz-Ponte et al., 1998), Phaeobacter inhibens from the German Wadden Sea (Martens et al., 2006), Phaeobacter arcticus from marine sediments of the Arctic Ocean (Zhang et al., 2008), Phaeobacter daeponensis from tidal flat sediment of the Yellow Sea (Yoon et al., 2007) and Phaeobacter caeruleus from a marine electroactive biofilm (Vandecandelaere et al., 2009).

The present study describes a novel bacterial isolate, strain $306^{\top}$, isolated from marine sediments of the Mediterranean Sea.

In October 2008, a sediment core was recovered in the Gulf of Lions $\left(42^{\circ} 41.596^{\prime} \mathrm{N}, 03^{\circ} 50.493^{\prime} \mathrm{E}\right.$; Water depth: $291 \mathrm{~m}$ ), in the Western Mediterranean Sea and subsampled for microbiological analyses as described elsewhere (Ciobanu et al., 2012). An anoxic sediment sample from $109 \mathrm{~cm}$ below the sea floor was spread on an agar plate composed 
of artificial seawater (Ciobanu et al., 2012) and glucose $(10 \mathrm{mM})$ and then incubated at $20^{\circ} \mathrm{C}$. After 10 days of incubation, a beige colony was picked, purified by repeated streaking on marine agar 2216 (MA; Difco) plates and referenced as strain $306^{\mathrm{T}}$. Stock cultures were stored at $80^{\circ} \mathrm{C}$, in marine broth 2216 (MB, Difco) supplemented with 5\% (v/v) DMSO, until characterization.

Both strands of the almost complete $16 \mathrm{~S}$ rRNA gene of strain $306^{\mathrm{T}}$ were amplified from a single colony using the universal primers 8F, 1492R (DeLong et al., 1992) and Eubint (5'-GCG CCA GCA GCC GCG GTA A-3'), and then sequenced with the Bid Dye technology (Beckman Coulter Genomics, Essex, UK). Contiging was performed from 5 overlapping sequence fragments. The sequence obtained was a continuous stretch of $1355 \mathrm{bp}$. Phylogenetic analyses were done with SeaView4 using the Muscle Multiple Alignment option to align sequences. Sequences of the nearest neighbors used to perform the alignment were imported from the Ribosomal Database Project (RDP) website. Phylogenetic trees were constructed using the SeaView4 software, on the basis of Neighbour Joining and PhyML (GTR model) algorithms. The robustness of the inferred topologies was assessed by bootstrap analyses based on 1000 replications. Percentages of sequence identity were calculated under BioEdit with the Sequence Identity Matrix calculation option. The $16 \mathrm{~S}$ rRNA gene-based analysis located the strain $306^{\mathrm{T}}$ within the class Alphaproteobacteria, in the bacterial domain. The results of different phylogenetic reconstructions performed with two treeing algorithms located the novel isolate within the genus Phaeobacter, order Rhodobacterales (Fig. 1). Within this genus, the novel isolate clustered with Phaeobacter arcticus (Zhang et al., 2008), sharing 98.7\% 16S rRNA gene 
sequence similarity with the type strain of this species, suggesting that the novel isolate may represent a novel species of the genus Phaeobacter (Stackebrandt \& Ebers, 2006). However, with the data set used for the phylogenetic reconstruction, the genus Phaeobacter does not form a monophyletic group (Fig. 1). This inconsistency between tree topology and taxonomy has already been observed in previous phylogenetic reconstructions including Phaeobacter and Leisingera species (Yoon et al., 2007). This may highlight the need for further taxonomic revision and the existence of a complex Leisingera/Phaeobacter group. Considering that the genus Leisingera encompasses only two species and displays a short phylogenetic distance with the presently described members of the genus Phaeobacter, it is also possible that this topology is a phylogenetic artefact. DNA-DNA hybridization experiments were performed to further elucidate the taxonomic position of strain $306^{\mathrm{T}}$ and to determine its DNA-DNA relatedness value with respect to $P$. arcticus DSM $23566^{\mathrm{T}}$. They were performed by the Identification Service of the Deutsche Sammlung von Mikroorganismen und Zellkulturen (DSMZ, Braunschweig, Germany), as described by De Ley et al. (1970), with the modifications described by Huss et al. (1983), using a Cary 100 Bio UV/VIS-spectrophotometer. Level of DNA-DNA relatedness between strain $306^{\mathrm{T}}$ and $P$. arcticus was far below the threshold value of $70 \%(9.8 \%)$, suggesting that strain $306^{\mathrm{T}}$ represents a novel species.

The DNA G+C content was determined by the Identification service of the DSMZ, by HPLC analysis, from the ratio of deoxyguanosine $(\mathrm{dG})$ and thymidine $(\mathrm{dT})$ according to the method of Mesbah et al. (1989). The DNA G+C content of strain $306^{\mathrm{T}}$ was $58.8 \mathrm{~mol} \%$. 
112 Colonies of the novel isolate on MA were smaller than $1 \mathrm{~mm}$ in diameter after 3 days 113 incubation, beige-pigmented, regularly circular, convex, creamy, smooth with an entire edge.

114 Morphological characteristics of the cells were determined by light microscopy (Olympus

115 BX60), by scanning electron microscopy (FEI Quanta 200) and by transmission electron 116 microscopy (Jeol JEM 100 CX II). SEM observations were done after a standard HMDS-based 117 (HexaMethylDiSilasane) preparation and TEM observations after negative staining with uranyl 118 acetate $(2 \% \mathrm{v} / \mathrm{v})$. Briefly, cells of strain $306^{\mathrm{T}}$ were short thickset rods or oval-shaped cells of 0.7-

$1192 \mu \mathrm{m}$ in length (mean $1.5 \pm 0.37, \mathrm{n}=30$ ) and $0.4-1 \mu \mathrm{m}$ in width (mean $0.58 \pm 0.07, \mathrm{n}=30$ ) in the 120 mid-exponential phase of growth (see supplementary Fig. S1a and S1b in IJSEM Online). Cells 121 could occur singly but formed often chains of about 5 cells or were grouped in aggregates of up 122 to 30 cells (Fig. S1a). They divided by constriction (Fig. S1b). Cells were flagellated and highly 123 motile. Gram staining was performed as described by Gerhardt et al. (1994), except that the 124 discoloration step was done with ethanol 70\% (v/v); Cells stained Gram-negative. Formation of 125 spores was never observed. cultures grown for 4-5 days in $\mathrm{MB}$, at $20^{\circ} \mathrm{C}$ with shaking $(90 \mathrm{rpm})$. The following 129 procedures were used: the determination of whole-cell fatty acid composition was done by the 130 standard protocol of the Sherlock Microbial Identification System (MIDI Inc, Newark, USA) 131 (Kuykendall et al., 1988), the analysis of respiratory quinones was carried out by thin layer 132 chromatography and then by HPLC, as described elsewhere (Tindall, 1990a, 1990b), and 133 separation of polar lipids was performed by two dimensional silica gel thin layer chromatography 
134 followed by a revelation of total lipids and specific functional groups, as described elwewhere 135 (Bligh and Dyer, 1959; Tindall et al., 2007). Strain $306^{\mathrm{T}}$ contained Q-10 as the unique respiratory 136 quinone. The main polar lipids included phosphatidylethanolamine, phosphatidylglycerol, 137 phosphatidylcholine, diphosphatidylglycerol, an unidentified aminolipid and two unidentified 138 lipids (Fig.S3). The cellular fatty acids $(>1 \%)$ in strain $306^{\mathrm{T}}$ comprised $\mathrm{C}_{18: 1} \omega 7 c, \mathrm{C}_{16: 0}$, 11139 methyl $\mathrm{C}_{18: 1} \omega 7 c, \mathrm{C}_{10: 0} 3-\mathrm{OH}, \mathrm{C}_{18: 0}$ and an unidentified cellular fatty acid with an equivalent chain 140 length (ECL) of 11.799 (Table S1). The presence of $\mathrm{C}_{18: 1} \omega 7 c$ together with Q-10 is typical of the 141 vast majority of taxa within the Alphaproteobacteria. Phaeobacter arcticus and strain $306^{\mathrm{T}}$ 142 appear to be the only members of the genus Phaeobacter that do not produce $\mathrm{C}_{12: 0} 3-\mathrm{OH}$. These 143 chemotaxonomic characteristics, and especially the quinone content and polar lipid pattern, 144 support the affiliation of strain $306^{\mathrm{T}}$ to the genus Phaeobacter.

145 Unless stated otherwise, physiological characterization was carried out aerobically in MB 146 medium in triplicate and the cell suspension was incubated with shaking in the dark. The 147 determination of temperature, $\mathrm{pH}$ and $\mathrm{NaCl}$ ranges for growth were done in $10 \mathrm{ml}$ aerobic tubes 148 of MB. Growth was monitored routinely by measuring the increase in optical density at $600 \mathrm{~nm}$ 149 using a Spectronic 401 spectrophotometer. Cell numbers were determined by direct cell counting 150 using a modified Thoma chamber (depth $10 \mu \mathrm{m})$. Growth rates were calculated using linear 151 regression analysis of five to nine points along the linear portions of the growth curves 152 logarithmically-transformed. The determination of the temperature range for growth was tested 153 over the range $4-37^{\circ} \mathrm{C}$ (i.e. $4,10,17,22,30,32,34,36,37^{\circ} \mathrm{C}$ ). The strain was found to be 154 mesophilic (Fig.S2), growing at $4-32^{\circ} \mathrm{C}$ (optimally $17-22^{\circ} \mathrm{C}$ ), but no growth occurred at $34^{\circ} \mathrm{C}$. 155 Salt tolerance was tested at $20^{\circ} \mathrm{C}$ in $\mathrm{MB}$ prepared with various concentrations of $\mathrm{NaCl}(0,0.5,2$, 
$3,4,6,8,15$ and $30 \% \mathrm{w} / \mathrm{v})$. The $\mathrm{NaCl}$ concentrations allowing growth ranged from $0.5 \%(\mathrm{w} / \mathrm{v})$ to $6 \% \mathrm{NaCl}$, with an optimum at $2 \%$. No growth was observed at $8 \%(\mathrm{w} / \mathrm{v}) \mathrm{NaCl}$ or without $\mathrm{NaCl}$. The $\mathrm{pH}$ range for growth was tested from initial $\mathrm{pH} 3.0$ to initial $\mathrm{pH} 11.0$, at ambiant temperature, in basal $\mathrm{MB}$ medium buffered and adjusted to the required $\mathrm{pH}$ (initial $\mathrm{pH}$ at $20{ }^{\circ} \mathrm{C}$ ), as described elsewhere (Alain et al., 2002). Growth was observed from $\mathrm{pH} 6.5$ to $\mathrm{pH} 9.0$, the optimum being around $\mathrm{pH} 8.0-9.0$. No growth was observed at $\mathrm{pH} 6.0$ and below, neither at pH10.

Biochemical characteristics of strain $306^{\mathrm{T}}$ were determined, in duplicates, at $25^{\circ} \mathrm{C}$ by using Api20E and Api20NE microplates (Biomerieux) according to the manufacturer's instructions. These galleries were inoculated with cells grown on MB plates and suspended in a $3 \%(\mathrm{w} / \mathrm{v})$ $\mathrm{NaCl}$ solution. These tests indicated that strain $306^{\mathrm{T}}$ was weakly positive for trisodium citrate assimilation, phenylacetic acid assimilation (Api20NE), capric acid oxidation and positive for phenylacetic acid oxidation. To investigate the capacity of the strain to catabolize different substrates as sole carbon and energy sources with oxygen as a terminal electron acceptor, the strain was grown in the dark, on the mineral basis of MB medium (depleted of all carbon and energy sources) supplemented with one substrate: cellulose, $\mathrm{D}(+)$ cellobiose dextrin $\mathrm{D}(+)$ galactose $\mathrm{D}(-)$ fructose $\mathrm{D}(+)$ lactose $\left(1 \mathrm{~g} .1^{-1}\right)$, maltose, $\mathrm{D}(+)$ mannose, $\mathrm{D}(+)$ rhamnose, $\mathrm{D}(-$ )ribose, sucrose, $\mathrm{L}(+)$ arabinose, $\mathrm{D}(+)$ xylose, $(\mathrm{D}+)$ trehalose for sugars (all at $10 \mathrm{mM}$ ), betaine succinate malonate, malate, ascorbate, acetate, propionate, fumarate, lactate, citrate for organic acids (all at $1 \mathrm{mM}$ ), ethanol, isopropanol, glycerol, $\mathrm{D}(-)$ sorbitol, mannitol for alcohols (all at 1\% w:v), L-alanine, L-arginine, L-aspartate, L-asparagine, L-cysteine, L-glutamine, L-glutamate, L- 
178 glycine, L-histidine, L-isoleucine, L-leucine, L-lysine, L-methionine, L-phenylalanine, L-proline, 179 L-serine, L-threonine, L-tryptophane, L-tyrosine, L-valine for amino acids (all at $1 \mathrm{mM}$ ) and 180 elastine, collagene and keratine for proteins (all at $1 \mathrm{~g} \cdot \mathrm{l}^{-1}$ ). Tween 80 degradation was investigated 181 on Noble agar (Sigma-Aldrich) plates prepared with the mineral basis of MB medium and 182 covered of the susbtrate $(0.75 \mathrm{mM})$. Metabolic properties of strain $306^{\mathrm{T}}$ are summarized in Table 1831 and in the species description. The ability of the strain to grow anaerobically and to ferment 184 complex organic matter or carbohydrates (yeast-extract 1 g. $\mathrm{l}^{-1}$, peptone 5 g. $\mathrm{l}^{-1}$ and glucose 10 $185 \mathrm{mM})$ was investigated under an atmosphere of $\mathrm{N}_{2}(100 \%)$ on a degassed and reduced $\mathrm{MB}$ 186 medium. The obligately anaerobic fermentative bacterium Aminomonas paucivorans was used as a control. Strain $306^{\mathrm{T}}$ does not ferment proteinaceous substrates not carbohydrates. Reduction of nitrate was tested in sulfate depleted mineral basis with $10 \mathrm{mM}$ of nitrate as terminal electron 189 acceptor and $10 \mathrm{mM}$ of succinate as carbon source. As control, Shewanella profunda, a nitrate 190 reducing bacterium, was used. The novel isolate does not respire nitrate.

191 Susceptibility to antibiotics was investigated, at $20^{\circ} \mathrm{C}$, on MA plates using the diffusion disc 192 method. Resistance to ampicillin, vancomycin, streptomycin, chloramphenicol (diluted in 193 ethanol), kanamycin, rifampicin (diluted in DMSO), penicillin G and tetracycline was 194 investigated at 10, 30 and $100 \mu \mathrm{g}$. Results were read after 4 days incubation and scored as 195 positive at zone diameters above $10 \mathrm{~mm}$. Strain $306^{\mathrm{T}}$ was susceptible to all antibiotics but for 196 different quantities of antibiotic : $10 \mathrm{ng}$ for chloramphenicol, ampicillin, rifampicin and penicillin 197 G, 30 ng for streptomycin, kanamycin and tetracycline, and $100 \mathrm{ng}$ for vancomycin. The results 198 of the phenotypic analyses are detailed in the species description and in Table 1. 
In conclusion, strain $306^{\mathrm{T}}$ branches with the genus Phaeobacter. Its phenotypic

201 chemotaxonomic and genotypic properties described herein generally coincide with the minimal

202 characteristics described for this taxon (Martens et al., 2006), thus confirming the belonging to

203 this genus. Within this genus, the novel isolate is most closely related to Phaeobacter arcticus,

204 but exhibits a low DNA-DNA relatedness with the type strain of this species, indicating that

205 these strains represent two distinct genomic species. In addition to the genomic distance, strain

$206306^{\mathrm{T}}$ can be distiguished from Phaeobacter arcticus in terms of a number of phenetic features.

207 These distinctive criteria are detailed in Table 1. In brief, the novel taxon differs from P. arcticus

208 strain $20188^{\mathrm{T}}$ by its temperaure $\left(4-32^{\circ} \mathrm{C}\right), \mathrm{NaCl}(0.5-6 \%)$ and $\mathrm{pH}(6.5-9)$ ranges for growth, its

209 DNA G+C content and its utilization profile of carbon sources. In conclusion, in view of all the

210 above-mentioned distinctive features, we propose that the isolate $306^{\mathrm{T}}$ should be assigned as the

211 type strain of a novel species, for which the name Phaeobacter leonis sp. nov. is proposed.

\section{Description of Phaeobacter leonis sp. nov}

(le.o'nis., L. gen n. leonis, of a lion, named after sinus Leonis the Medieval Latin name of Gulf of Lions, in reference to the origin of the type strain).

Cells are Gram-negative, rod- or oval-shaped, 0.7-2.5 $\mu \mathrm{m} \times 0.4-1 \mu \mathrm{m}$ in size and motile. Colonies on MA are beige, regularly circular, convex, translucent, smooth with an entire edge and creamy. The strain grows aerobically and produces catalase and cytochrome oxidase. Growth occurs at $4-32^{\circ} \mathrm{C}$ with an optimum at $17-22^{\circ} \mathrm{C}$, pH $6.5-9$ with an optimum at $8-9$ and with $\mathrm{NaCl}$ concentration ranging fom $0.5-6 \%(\mathrm{w}: \mathrm{v})$ with an optimum at $2 \%$. Negative for nitrate reduction, indole formation, arginine dihydrolase, urease, lysine decarboxylase, ornithine 
decarboxylase, tryptophan deaminase, gelatinase, $\beta$-glucosidase, $\beta$-galactosidase, glucose assimilation, $\mathrm{N}$-acetyl-glucosamine assimilation, potassium gluconate assimilation, capric acid assimilation, adipic acid assimilation, malic acid assimilation. Positive for phenylacetic assimilation. Weakly positive for trisodium citrate assimilation, phenylacetic oxidation and capric acid oxidation. The following substrates are used as sole carbon source : $\mathrm{L}(+)$ arabinose, succinate, propionate, fumarate, ethanol, L-alanine, L-asparagine, L-threonine, L-leucine, Lphenylalanine, keratine, collagene, $\mathrm{D}(-)$ trehalose, $\mathrm{D}(-)$ fructose, $\mathrm{D}(+)$ mannose, $\mathrm{D}(+)$ rhamnose, D(-)ribose, sucrose, citrate, D-mannitol, L-arginine, L-glutamine, L-methionine, L-serine, Lproline, L-glycine, L-tryptophan, L-tyrosine, L-isoleucine, keratine and collagene. The following substrates are not used as sole carbon source : dextrine, cellulose, $\mathrm{D}(+)$ cellobiose, $\mathrm{D}(+)$ glucose, maltose, $\mathrm{D}(+) x y l o s e$, betaine, malonate, acetate, malate, ascorbate, lactate, isoropanol, glycerol, sorbitol, L-glutamate, L-histidine, L-valine, L-cysteine, L-leucine, L-aspartate and elastine.

The main fatty acids comprise $\mathrm{C}_{18: 1} \quad \omega 7-\mathrm{c}$ and $\mathrm{C}_{16: 00}$. The main polar lipids are diphosphatidylglycerol, phosphatidylglycerol, phosphatidylethanolamine, phosphatidylcholine, an unidentified aminolipid and 2 unidentified polar lipids. Ubiquinone-10 (Q-10) is the only isoprenoid quinone. The DNA G $+\mathrm{C}$ content is around $59 \mathrm{~mol} \%$.

The type strain, $306^{\mathrm{T}}\left(\mathrm{DSM} 25627^{\mathrm{T}}\right.$, CIP $110369^{\mathrm{T}}$, UBOCC $3187^{\mathrm{T}}$ ) was isolated from sediments collected at $109 \mathrm{~cm}$ below the sea floor, in the Gulf of Lions, in the Western Mediterranean Sea.

\section{Acknowledgements}


We acknowledge Professor J. P. Euzéby for support in the latin etymologies of the species name. We thank Gérard Sinquin and Nicolas Gayet for assistance with the transmission and scanning electron microscopes. We thank the crew and the chief scientists (S. Berné and B. Dennielou) of the Rhosos oceanographic cruise for helping us to collect sediment samples. This work was financially supported by the Joint Research Unit UMR 6197 (CNRS-Ifremer-UBO), by the project SEDAAMIC (2011) and SEDAMIC II (2012) funded by the program INTERRVIE of the INSU (CNRS) and by the project PALEOMIC funded by the program "Projets Exploratoires 2011” of the Université de Bretagne Occidentale (UBO). F. Gaboyer was awarded with a PhD scholarship by the Région Bretagne and by the French Ministry of Higher Education and Research .

\section{References}

Alain, K., Querellou, J., Lesongeur, F., Pignet, P., Crassous, P., Raguénès, G., Cueff, V. \& Cambon Bonavita, M.-A. (2002). Caminibacter hydrogeniphilus gen. nov., sp. nov., a novel thermophilic, hydrogen-oxidizing bacterium isolated from an East Pacific Rise hydrothermal vent. Int J Syst Evol Microbiol 52, 1317-1323.

Bligh, E. \& Dyer, W. (1959). A rapid method of total lipid extraction and purification. Canadian $J$ Biochem Physiol 37, 911-917.

Ciobanu, M.-C., Rabineau, M., Droz, L., Révillon, S., Ghiglione, J.-F., Dennielou, B., Jorry, S., Kallmeyer, J., Etoubleau, J., Pignet, P., Crassous, P., Laugier, J., Guégan, M., Godfroy, A. \& Alain, K. (2012). Sedimentological imprint on subseafloor bacterial and archaeal communities in Mediterranean Sea Quaternary sediments. Biogeosciences 9, 3491-3512. 
De Ley, J., Cattoir, H. \& Reynaerts, A. (1970). The quantitative measurement of DNA hybridization from renaturation rates. Eur J Biochem 12, 133-142.

DeLong, E. F. (1992). Archaea in coastal marine environments. Proc Nat Acad Sci USA 89, 5685-5689.

Gerhardt, P., Murray, R., Wood, W. \& Krieg, N. (1994). Methods for General and Molecular Bacteriology. $1^{\text {st }}$ edition. Washington, DC: American Society for Microbiology Press.

Huss, V. A. R., Festl, H. \& Schleifer, K. H. (1983). Studies on the spectrophotometric determination of DNA hybridization from renaturation rates. Syst Appl Microbiol 4, 184-192.

Kuykendall, L., Roy, M., O'neill, J. \& Devine, T. (1988). Fatty acids, antibiotic resistance, and deoxyribonucleic acid homology groups of Bradyrhizobium japonicum. Int J Syst Bacteriol 38, 358 361.

Martens, T., Heidorn, T., Pukall, R., Simon, M., Tindall, B. \& Brinkhoff, T. (2006). Reclassification of Roseobacter gallaeciensis Ruiz-Ponte et al. 1998 as Phaeobacter gallaeciensis gen. nov., comb. nov., description of Phaeobacter inhibens sp. nov., reclassification of Ruegeria algicola (Lafay et al. 1995) Uchino et al. 1999 as Marinovum algicola gen. nov., comb. nov., and emended descriptions of the genera Roseobacter, Ruegeria and Leisingera. Int J Syst Evol Microbiol 56, 1293-1304.

Mesbah, M., Premachandran, U. \& Whitman, W. (1989). Precise measurement of the G+C content of deoxyribonucleic acid by high performance liquid chromatography. Int J Syst Bacteriol 39, 159-167.

Ruiz-Ponte, C., Cilia, V., Lambert, C. \& Nicolas, J. (1998). Roseobacter gallaeciensis sp. nov., a new marine bacterium isolated from rearings and collectors of the scallop Pecten maximus. Int $J$ Syst Bacteriol 48, 537-542.

Stackebrandt, E. \& Ebers, J. (2006). Taxonomic parameters revisited: tarnished gold standards. Microbiol Today 33, 152-155.

Tindall, B. (1990a). A comparative study of the lipid composition of Halobacterium saccharovorum from various sources. Syst Appl Microbiol 13, 128-130. 
Tindall, B. (1990b). Lipid composition of Halobacterium lacusprofundi. FEMS Microbiol Lett 66, 199202.

Tindall, B., Sikorski, J., Smibert, R.A. \& Krieg, N.R. (2007). Phenotypic Characterization and the Principles of Comparative Systematics. In Methods for General and Molecular Microbiology. $3^{\text {rd }}$ edition. pp 330-393. Edited by C. A. Reddy, Terry J. Beveridge, John A. Breznak, George Marzluf, Thomas M. Schmidt, Loren R. Snyder. Washington DC: ASM Press.

Vandecandelaere, I., Segaert, E., Mollica, A., Faimali, M. \& Vandamme, P. (2009). Phaeobacter caeruleus sp. nov., a blue-coloured, colony-forming bacterium isolated from a marine electroactive biofilm. . Int J Syst Evol Microbiol 59, 1209-1214.

Yoon, J.-H., Kang, S.-J., Lee, S.-Y. \& Oh, T.-K. (2007). Phaeobacter daeponensis sp. nov., isolated from a tidal flat of the Yellow Sea in Korea Int J Syst Evol Microbiol 57, 856-861.

Zhang, D.-C., Li, H.-R., Xin, Y., Liu, H.-C., Chi, Z.-M., Zhou, P.-J. \& Yu, Y. (2008). Phaeobacter arcticus sp. nov., a psychrophilic bacterium isolated from the Arctic. Int J Syst Evol Microbiol 58, $1384-1387$.

\section{Tables and figures}




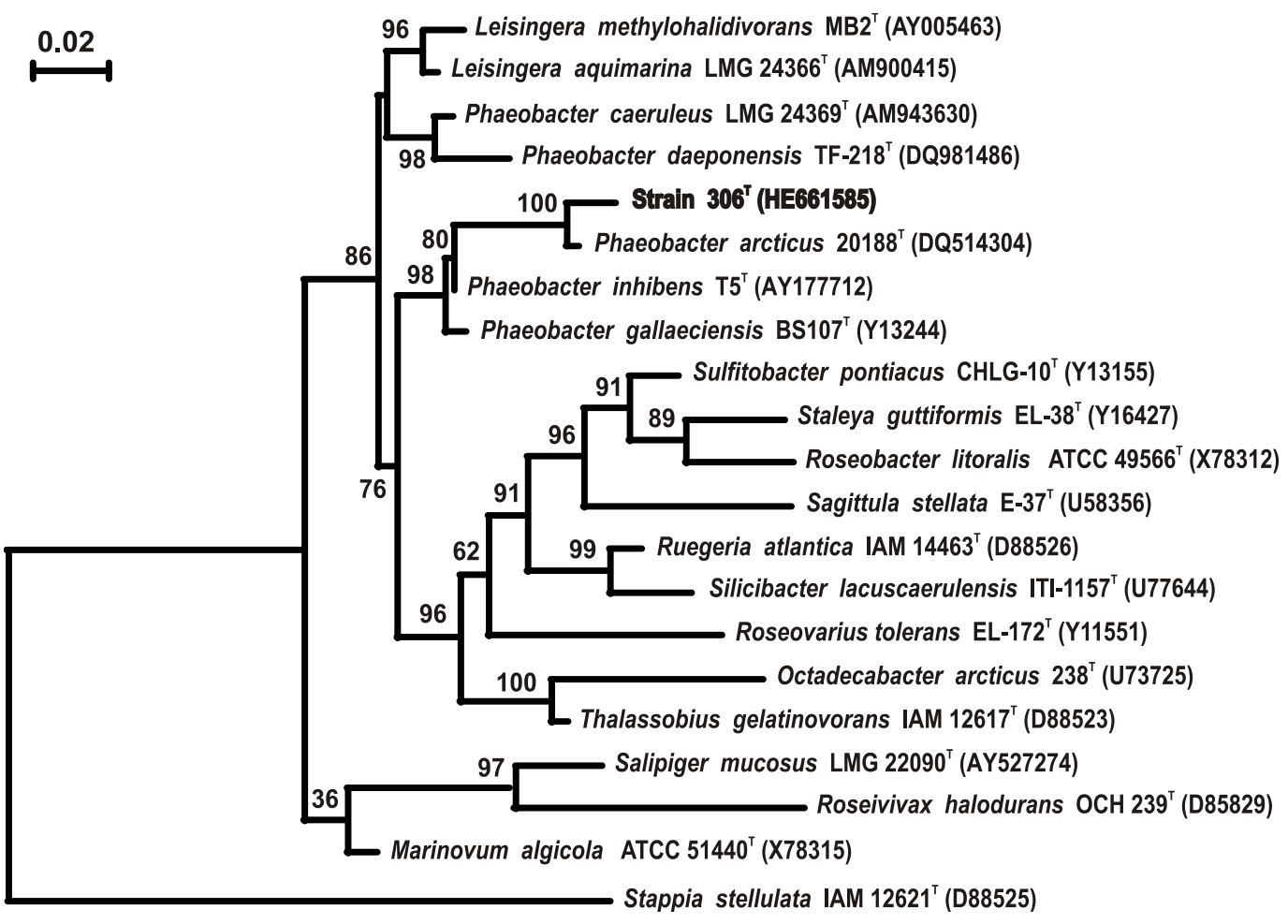

FIG. 1. Phylogenetic tree based on 16S rRNA gene sequences showing the relationships between strain $306^{\mathrm{T}}$ and its nearest phylogenetic neighbours. The topology shown was calculated with the maximum likelihood algorithm. Accession numbers are indicated in brackets. Bootstrap values (\%) are indicated at the branch nodes and were calculated from 1000 resample datasets. Stappia Stellulata was used as an outgroup.

312 
Table 1: Phenotypic characteristics that differentiate strain $306^{\mathrm{T}}$ from related species of the genus Phaeobacter.

Only the data related to strain $306^{\mathrm{T}}$ were experimentally obtained. Data concerning strains 2 to 6 were obtained from literature.

Taxa: 1, strain $306^{\mathrm{T}} ; 2$, P. arcticus (Zhang et al., 2008); 3, P. gallaeciensis (Ruiz-Ponte et al., 1998 ; Martens et al., 2006) ; 4, P. inhibens (Martens et al., 2006) ; 5, P. daeponensis (Yoon et al., 2007); 6, P. caeruleus (Vandecandelaere et al., 2009) +, Positive ; -, Negative ; ND, no data available; Y, Yes.

\begin{tabular}{|c|c|c|c|c|c|c|}
\hline Characteristic & 1 & 2 & 3 & 4 & 5 & 6 \\
\hline Motility & $\mathrm{Y}$ & $\mathrm{Y}$ & $\mathrm{Y}$ & $\mathrm{Y}$ & $\mathrm{Y}$ & $\mathrm{Y}$ \\
\hline Size $(\mu \mathrm{m})$ & $2.5-0.7 \times 1-0.4$ & $6.1-2.6 \times 0.5-0.3$ & $1 \times 1.5$ & $2.5-1.7 \times 1-0.7$ & $0.4-0.9 \times 0.7-2.0$ & $0.9 \times 1.8$ \\
\hline - Colony & Beige & Yellow & Brown & Brown & No pigment & Blue \\
\hline $\begin{array}{l}\text { - Temperature range } \\
\text { (opt) }\end{array}$ & $\begin{array}{c}4-32 \\
(17-22)\end{array}$ & $\begin{array}{l}0-25 \\
(20)\end{array}$ & $\begin{array}{l}<4-35 \\
(28)\end{array}$ & $\begin{array}{l}15-37 \\
(23-27)\end{array}$ & $\begin{array}{c}4-42 \\
(\mathrm{ND})\end{array}$ & $\begin{array}{l}4-45 \dagger \\
(20-28)\end{array}$ \\
\hline $\begin{array}{l}\text { - } \mathrm{pH} \text { range } \\
(\mathrm{opt})\end{array}$ & $\begin{array}{c}6.5-9 \\
(8-9)\end{array}$ & $\begin{array}{l}5-10 \\
(6-9)\end{array}$ & $\begin{array}{l}6-9.5 \\
(7.5)\end{array}$ & $\begin{array}{l}7-10 \\
(7)\end{array}$ & $\begin{array}{l}5.5-8 \\
(7-8)\end{array}$ & $\begin{array}{c}6-9 \\
(6.5-8)\end{array}$ \\
\hline $\begin{array}{l}-\mathrm{NaCl} \text { range } \% \mathrm{w}: \mathrm{v} \\
\text { (opt) }\end{array}$ & $\begin{array}{l}0.5-6 \\
(2)\end{array}$ & $2-9$ & $\begin{array}{l}0.06-9 \\
(3-4)\end{array}$ & $\begin{array}{l}0.6-11.5 \\
\quad(1.2)\end{array}$ & $\begin{array}{l}\mathrm{ND}-8 \% \\
\quad(\mathrm{ND})\end{array}$ & $\begin{array}{l}2-5 \dagger \\
(3-4)\end{array}$ \\
\hline $\begin{array}{l}\text { - Hydrolysis of : } \\
\text { Tween } 80\end{array}$ & - & nd & - & + & - & $t^{\$}$ \\
\hline $\begin{array}{l}\mathrm{D}(+) \text { cellobiose } \\
\text { - Growth with: }\end{array}$ & + & - & - & + & - & ND \\
\hline $\mathrm{L}(+)$ arabinose & + & $+\S$ & nd & - & - & -\$ \\
\hline $\mathrm{D}(+)$ cellobiose & - & $-\S$ & + & $+*$ & - & ND \\
\hline $\mathrm{D}(-)$ fructose & - & $+\S$ & + & $+*$ & - & ND \\
\hline $\mathrm{D}(+)$ galactose & - & $-\S$ & + & $+^{*}$ & - & ND \\
\hline $\mathrm{D}(-)$ maltose & - & $+\S$ & + & + & - & - \\
\hline Sucrose & + & $+\S$ & + & - & - & ND \\
\hline $\mathrm{D}(+)$ trehalose & + & $-\S$ & + & + & - & ND \\
\hline Betaine & - & ND & + & $+*$ & ND & ND \\
\hline $\mathrm{D}(-)$ lactate & + & $-\S$ & + & $+^{*}$ & ND & ND \\
\hline $\mathrm{D}(-)$ succinate & + & $-\S$ & - & $+*$ & + & ND \\
\hline Sorbitol & - & $-\S$ & + & + & - & ND \\
\hline L-glutamate & - & $-\S$ & + & + & - & ND \\
\hline L-leucine & - & $-\S$ & + & + & + & ND \\
\hline L-serine & + & $-\S$ & - & + & + & ND \\
\hline $\begin{array}{c}\text { - DNA G+C content } \\
(\mathrm{mol} \%)\end{array}$ & 58.8 & 59.6 & $57.6-58$ & 55.7 & 64.9 & 63.6 \\
\hline
\end{tabular}

* Utilization of these $\mathrm{C}$ sources was investigated in ASW medium with $10 \mathrm{mg} . \mathrm{l}^{-1}$ casein hydrolysate.

$\uparrow$ These characteristics were tested in R2A medium. \$ These characteristics were tested in trypticase soy broth medium.

$\S$ These characteristics were determined with Api20NE or Api20E galleries. 
1 Supplementary tables and figures
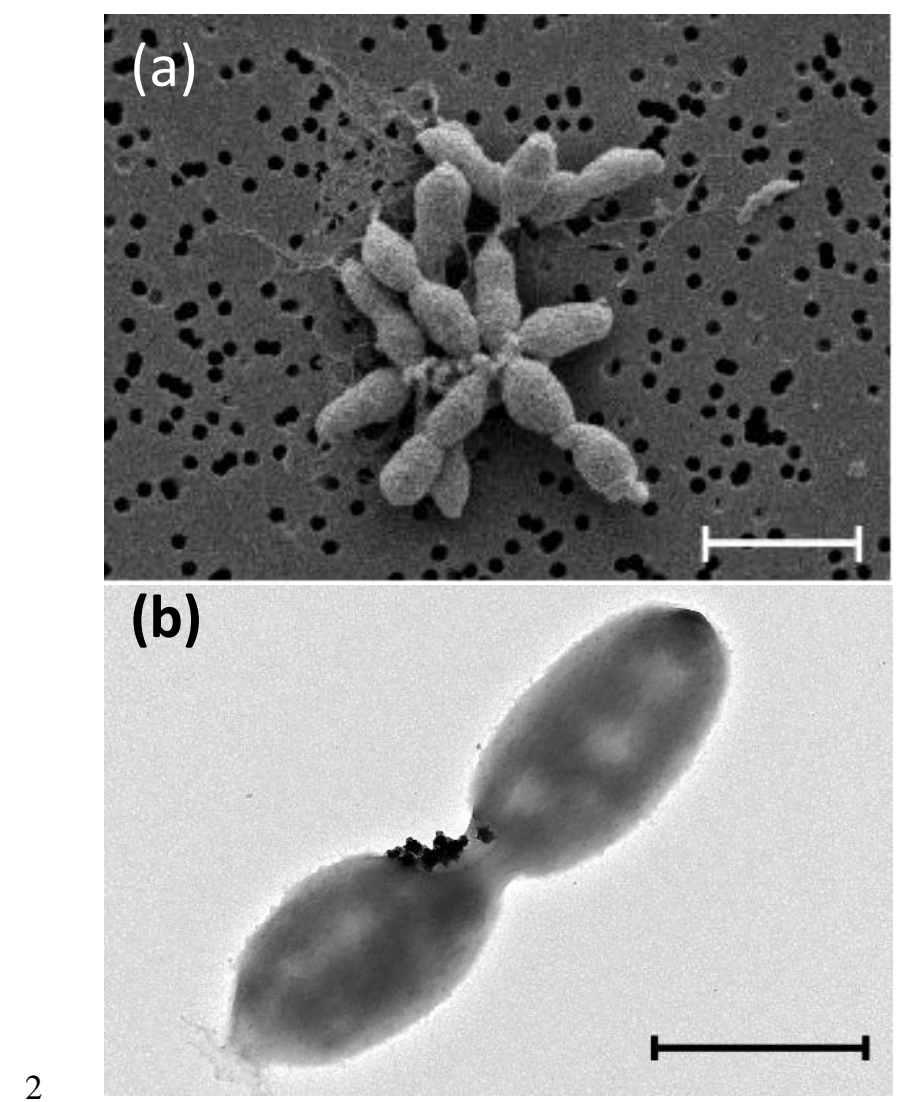

3 Fig. S1. Scanning (a) and transmission (b) electron micrographs of cells of strain $306^{\mathrm{T}}$ in 4 exponential growth phase showing cellular aggregates (a) and division by constriction (b). $5 \quad$ Bars, $2 \mu \mathrm{m}$ (a) and $1 \mu \mathrm{m}(\mathrm{b})$. 


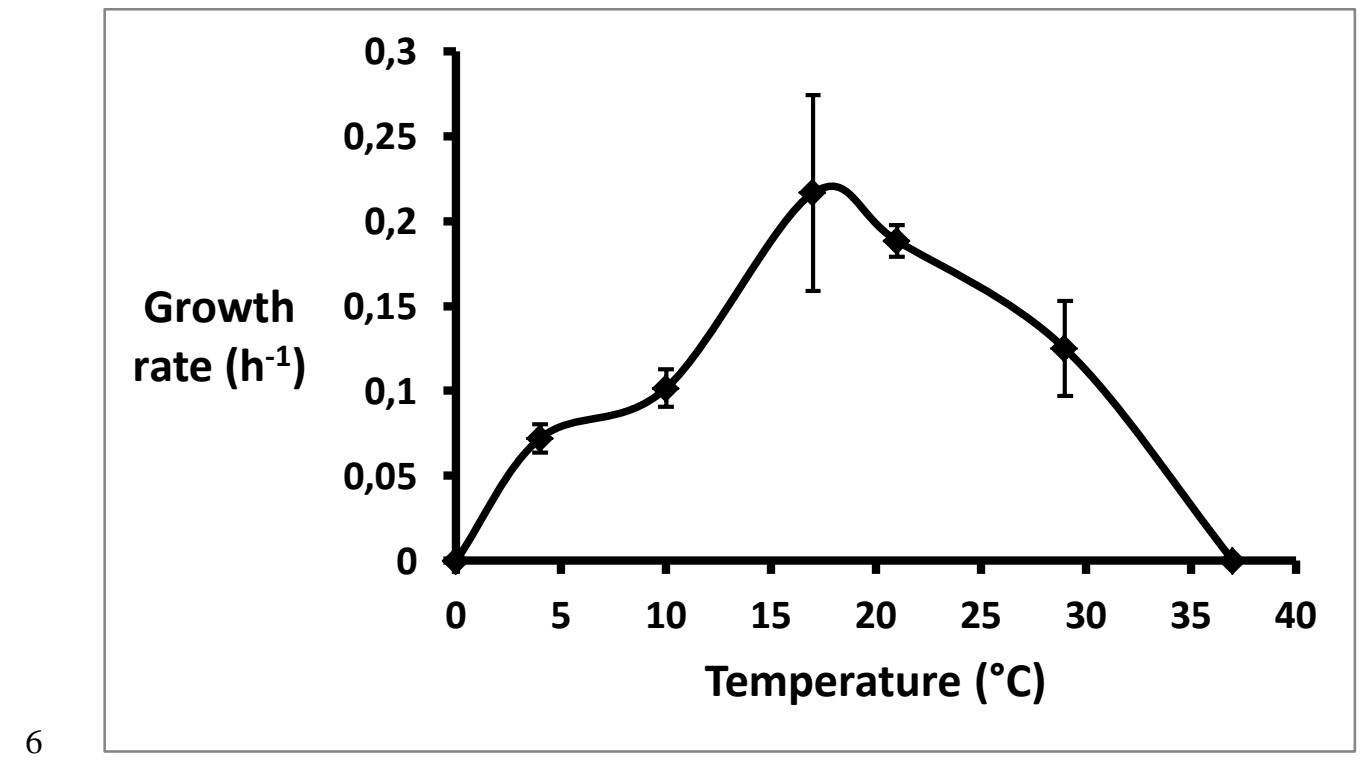

7 Fig. S2. Effects of temperature on the maximum growth rate of strain $306^{\mathrm{T}}$. Bars indicate 8 confidence intervals.

9 
10 Fig. S3. Polar lipids of strain $306^{\mathrm{T}}$ following separation by two-dimensional TLC. PE,

11 Phosphatidylethanolamine; PG, Phosphatidylglycerol; PC, Phosphatidylcholine; DPG,

12 Diphosphatidylglycerol; AL1, Unidentified aminolipid; L1-L2, Unidentified lipids.

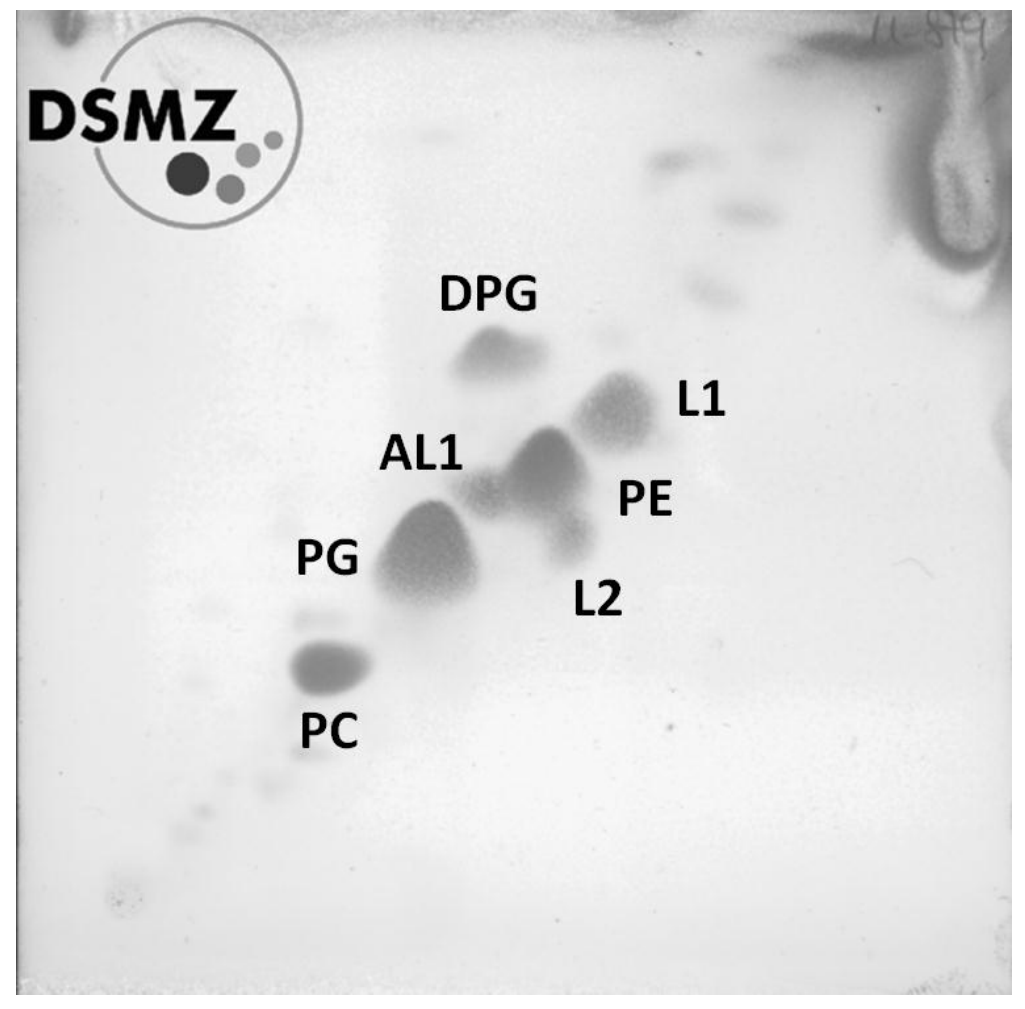


Table S1. Whole-cell fatty acid profile of mid to late exponential phase of growth cells of strain $306^{\mathrm{T}}$ cultivated on MB2216 medium. $92.28 \%$ of the fatty acid peaks could be assigned by the Sherlock Microbial Identification System (MIDI Inc, Newark, USA). Major fatty acids are indicated in bold. All data have been obtained on exponential phase of growth cultures grown on Marine Broth 2216 (Difco) or Marine Agar 2216 (Difco).

Species: 1, Strain $306^{\mathrm{T}} ; 2$, Phaeobacter arcticus $20188^{\mathrm{T}}$ (Zhang et al.); 3, Phaeobacter gallaeciensis (Yoon et al., 2007); 4, Phaeobacter inhibens (Yoon et al., 2007); 5, Phaeobacter daeponensis (Yoon et al., 2007); 6, P. caeruleus (Vandecandelaere et al., 2009).

Values are percentages of the total fatty acids. ND, Not detected.

Legend: ECL, equivalent chain-length. * Data from Ruiz-Ponte et al., 1998.**Summed feature 3 contains $\mathrm{C}_{16: 1} \omega 7 c$ and/or 2-OH iso- $\mathrm{C}_{15: 0}$ and summed feature 5 contains $\mathrm{C}_{18: 2} \omega 6,9 c$ and/or ante$\mathrm{C}_{18: 0}$.

\begin{tabular}{|c|c|c|c|c|c|c|}
\hline & \multicolumn{6}{|c|}{ Proportion (\%) } \\
\hline Fatty acid & 1 & 2 & 3 & 4 & 5 & 6 \\
\hline \multicolumn{7}{|l|}{ Saturated } \\
\hline $\mathrm{C}_{12: 0}$ & 0.23 & 0.86 & 0.4 & 0.4 & 1.2 & $<1 \%$ \\
\hline $\mathrm{C}_{16: 0}$ & 6.05 & 9.69 & 6.3 & 5.2 & 8.6 & 4.2 \\
\hline $\mathrm{C}_{17: 0}$ & 0.1 & ND & 0.2 & 0.2 & 0.6 & ND \\
\hline $\mathrm{C}_{18: 0}$ & 1.56 & 0.53 & 1.3 & 2.0 & 2.4 & 1.0 \\
\hline \multicolumn{7}{|c|}{ Monounsaturated } \\
\hline $\mathrm{C}_{18: 1} \omega 9 c^{*}$ & 0.14 & ND & 0.92 & 1.11 & ND & ND \\
\hline $\mathrm{C}_{18: 1} \omega 7 c$ & 84.11 & 44.63 & 74.5 & 70.8 & 57.7 & 81.5 \\
\hline $\mathrm{C}_{18: 1} \omega 5 c$ & 0.13 & ND & ND & ND & ND & ND \\
\hline $\mathrm{C}_{20: 1} \omega 7 c$ & 0.1 & ND & ND & ND & ND & ND \\
\hline \multicolumn{7}{|l|}{ Hydroxy } \\
\hline $3-\mathrm{OH} \mathrm{C} \mathrm{C}_{10: 0}$ & 1.75 & 6.75 & 1.9 & 1.8 & 1.7 & 2.8 \\
\hline
\end{tabular}




\begin{tabular}{|lcccccc|} 
2-OH C $16: 0$ & 0.65 & 3.95 & 2.7 & 2.8 & 5.6 & 2.4 \\
2-OH C $18: 1$ & 0.12 & 0.59 & ND & ND & ND & ND \\
Methyl-substituted & & & & & & \\
11 -methyl C $18: 1 \omega 7 c$ & 2.11 & 18.1 & 7.8 & 11.8 & 16.6 & 1.3 \\
Summed featured & & & & & & \\
Summed feature 3** & 0.18 & 2.30 & 0.3 & 0.2 & 0.5 & ND \\
$\begin{array}{l}\text { Summed feature 5** } \\
\begin{array}{l}\text { Unknown component } \\
\text { in the MIS database }\end{array}\end{array}$ & 0.16 & ND & ND & ND & ND & ND \\
ECL 11.799 & & & & & & \\
\hline
\end{tabular}

